\title{
EFFECT OF ADDITION OF DIFFERENT NITRATE CONCENTRATION ON Spirulina platensis BIOMASS WITH SEMI OUTDOOR SYSTEM
}

\author{
Natalia $^{1^{*}}$, Bintal Amin $^{2}$, Irwan Effendi ${ }^{2}$ \\ ${ }^{1}$ Student of The Faculty of Fisheries And Marine Science University of Riau, Pekanbaru \\ ${ }^{2}$ Lecturer at the Faculty of Fisheries And Marine Science University Riau, Pekanbaru \\ *Nataliamaloy@gmail.com
}

\begin{abstract}
Spirulina platensis is one type of microalgae that has high nutrient and protein content and can live in fresh and marine waters. In the growth of $S$. platensis requires several supporting factors in its growth period, one of which is nitrate $\left(\mathrm{NO}_{3}\right)$. Nitrate is needed in the formation of proteins and amino acids in cells and also helps in increasing biomass. This study was conducted with the aim to see the effect of adding different nitrate concentrations to $S$. platensis biomass with a semi-outdoor system. This research was conducted in MarchApril 2019 using the experimental method. Water quality parameters during the study obtained in the form of temperatures ranging from $29-30^{\circ} \mathrm{C}, \mathrm{pH} 9$ and salinity $25 \mathrm{ppt}$. The optimum nitrate concentration for the growth of S. platensis was at a concentration of $9 \mathrm{ppm}$ with a total biomass of 0.669 grams.
\end{abstract}

Keywords: Spirulina platensis, Nitrate, Biomass, Semi-Outdoor

\section{PENDAHULUAN}

Mikroalga sangat potensial untuk dikembangkan sebagai bahan baku biofuel jika dibandingkan dengan tanaman pangan karena mempunyai beberapa keuntungan antara lain pertumbuhan yang cepat, produktivitas tinggi, memungkinkan penggunaan air tawar dan air laut, dan biaya produksi yang tidak terlalu tinggi. Menurut Amini et al. (2010), bahwa mikroalga juga memiliki struktur sel yang sederhana, kemampuan fotosintesis yang tinggi, siklus hidup yang pendek, dapat mensintesis lemak, dapat bertahan pada kondisi lingkungan yang ekstrim serta tidak membutuhkan nutrisi yang banyak.

$S$. platensis tidak memiliki alat reproduksi seksual sehingga berkembang biak secara aseksual saja melalui pembelahan sel. Pembelahan sel dimulai dengan pembentukan membran transversal di dalam sel kemudian putus dan menghasilkan filamen yang memanjang sampai tahap dewasa (Rahayu, 2007).

S.platensis dalam hidupnya memiliki beberapa fase yaitu: fase adaptasi terjadi pada hari pertama dan ke-dua, kemudian fase eksponensial dimana tejadi peningkatan jumlah kepadatan Spirulina sp. pada hari ketiga hingga hari ke-tujuh. Fase stationer yaitu fase saat jumlah populasi Spirulina sp.cenderung tetap terjadi pada hari kedelapan hingga ke-11. Selanjutnya pada hari ke-12 hingga hari ke-15 terjadi fase deklinasi (kematian) (Ulya et al., 2018).

Protein dari $S$. platensis kering dapat mencapai lebih dari 60\%, kandungan vitaminnya tinggi terutama vitamin B12, serta mengandung asam amino yang cukup lengkap. Alga ini juga kaya akan gammalinolenic acid (GLA), dan juga menyediakan alpha-linolenic acid (ALA), linolenic acid (LA), stearidonic acid (SDA), eicosapentaeonic (EPA), docosahexaenoic 
acid (DHA), and arachidonic acid (AA). Vitamin yang terkandung didalamnya adalah vitamin B1, B2, B3, B6, B9, B12, Vitamin C, Vitamin D dan Vitamin E. Selain hal-hal tersebut ganggang ini juga mengandung potasium, kalsium, krom, tembaga, besi, magnesium, mangan, fosfor, selenium, sodium, dan seng. Sebuah studi 2 menyebutkan bahwa $S$. platensis memungkinkan membantu sistem imun dalam melawan infeksi (Susanna et al., 2007).

Nitrogen dan fosfor merupakan sebagian dari faktor sumberdaya tersebut. Nutrien utama pada media kultur mikroalga adalah $\mathrm{N}$, namun terkadang $\mathrm{N}$ pada media dalam bentuk anorganik seperti nitrit $\left(\mathrm{NO}_{2}\right)$ dan nitrat $\left(\mathrm{NO}_{3}\right)$, akan tetapi mikroalga umumnya dapat menggunakan $\mathrm{NO}_{3}, \mathrm{NO}_{2}$, atau amonium $\left(\mathrm{NH}_{4}\right)$ sebagai sumber $\mathrm{N}$ dengan tingkat pertumbuhan yang sama terlepas bentuknya organik maupun anorganik (Borowitzka, 1988).

Menurut Viena (2014), peningkatan biomassa mikroalga bertambah seiring dengan penambahan konsentrasi nitrat. Penambahan nitrat yang berbeda pada kultur mikroalga yang telah dikondisikan akan menunjukkan peningkatan jumlah biomassa yang signifikan.

Tujuan penelitian ini yaitu untuk mengetahui konsentrasi nitrat yang baik untuk pertumbuhan biomassa S. platensis yang dilakukan dengan sistem semi outdoor.

\section{METODE PENELITIAN}

Metode yang digunakan dalam penelitian ini adalah metode eksperimen dengan menggunakan RAL (Rancangan Acak Lengkap). Penelitian dilaksanakan pada bulan Maret - April 2019 yang bertempat di Laboratorium Kimia Laut dan Biologi Laut,Universitas Riau dengan peletakan wadah penelitian dengan sistem semi outdoor. Media yang digunakan yaitu Media Guillard atau F/2.
Parameter Kualitas Air yang diukur pada penelitian ini meliputi Suhu dan $\mathrm{pH}$, sedangkan pada Salinitas diukur dan ditetapkan 25 ppt selama penelitian. Konsentrasi $\mathrm{NO}_{3}$ yang digunakan pada yaitu nitrat dengan konsentrasi 7 ppm, 9 ppm dan 11 ppm. Pengukuran kadar nitrat dilakukan selama 3 kali selama penelitian dan diukur dengan menggunakan Spectofhotometer.

Biomassa S. platensis diukur 3 kali selama proses penelitian. Perhitungan biomassa menggunakan timbangan analitik dimana sampel $S$. platensis yang telah di saring kemudian dimasukkan kedalam oven selama 4 jam dengan suhu $105^{\circ} \mathrm{C}$. Setelah dioven sampel tersebut di timbang dengan menggunakan timbangan analitik. Perhitungan kultur stok Spirulina sp. yang digunakan untuk kultur mengacu pada BPPT (2013).

\section{HASIL DAN PEMBAHASAN Parameter Kualitas Air}

Parameter kualitas air yang didapatkan selama proses kultur $S$. platensis pada suhu dihasilkan nilai $29^{\circ} \mathrm{C}-30^{\circ} \mathrm{C}$, nilai $\mathrm{pH} 9$ dan salinitas 25 ppt.

\section{Pengukuran Kadar Nitrat Pada Kultur $S$. platensis dengan Sistem Semi Outdoor}

Hasil dari pengukuran kadar nitrat yang dilakukan selama proses kultur dapat dilihat pada Gambar 1 :

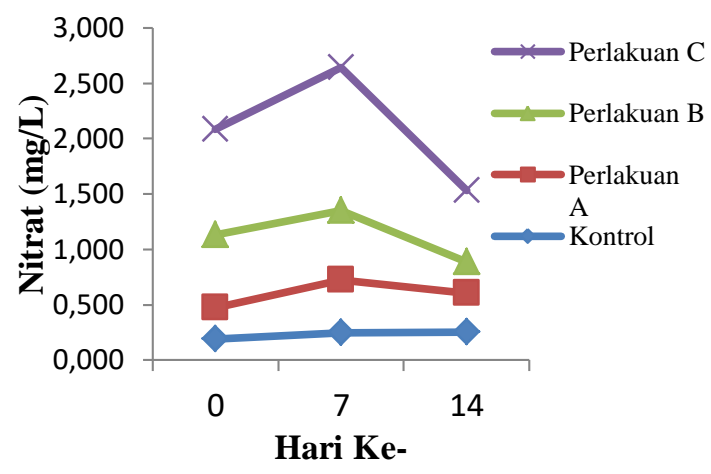

Gambar 1. Kadar Nitrat pada kultur S.platensis dengan Sistem Semi Outdoor.

Pengukuran nitrat hari ke-0 pada Kontrol hasil pengukuran nitrat menunjukkan 
hasil 0,193 $\mathrm{mg} / \mathrm{L}$, pada hari ke-7 mengalami kenaikan menjadi $0,245 \mathrm{mg} / \mathrm{L}$ , dan pada hari ke-14 mengalami kenaikan menjadi $0,255 \mathrm{mg} / \mathrm{L}$.

Perlakuan A memiliki kadar nitrat pada hari ke-0 yaitu $0,279 \mathrm{mg} / \mathrm{L}$, pada hari ke-7 kadar nitrat mengalami kenaikan menjadi $0,479 \mathrm{mg} / \mathrm{L}$ dan pada hari ke-14 kadar nitrat mengalami penurunan menjadi $0,352 \mathrm{mg} / \mathrm{L}$. Pada perlakuan B kadar nitrat pada hari ke-0 yaitu $0,625 \mathrm{mg} / \mathrm{L}$, pada hari ke-7 kadar nitrat mengalami kenaikan menjadi 0,662 $\mathrm{mg} / \mathrm{L}$ dan pada hari ke-14 kadar nitrat mengalami penurunan menjadi 0,280 $\mathrm{mg} / \mathrm{L}$. Pada perlakuan $\mathrm{C}$ kadar nitrat pada hari ke-0 yaitu $0,954 \mathrm{mg} / \mathrm{L}$, pada hari ke7 kadar nitrat mengalami kenaikan menjadi 1,296 mg/L dan pada hari ke-14 kadar nitrat mengalami penurunan menjadi $0,648 \mathrm{mg} / \mathrm{L}$.

untuk pertumbuhannya hal ini sesuai dengan pernyataan Borowitzka (1988) yang menyatakan bahwa nutrien utama pada media kultur mikroalga adalah $\mathrm{N}$, namun terkadang $\mathrm{N}$ pada media dalam bentuk anorganik seperti nitrit $\left(\mathrm{NO}_{2}\right)$ dan nitrat $\left(\mathrm{NO}_{3}\right)$, akan tetapi mikroalga umumnya dapat menggunakan $\mathrm{NO}_{3}$, $\mathrm{NO}_{2}$, atau amonium $\left(\mathrm{NH}_{4}\right)$ sebagai sumber $\mathrm{N}$ dengan tingkat pertumbuhan yang sama terlepas bentuknya organik maupun anorganik.

\section{Penambahan Konsentrasi Nitrat yang Berbeda Terhadap Biomassa Spirulina platensis dengan Sistem Semi Outdoor}

Hasil penambahan kadar nitrat dengan konsentrasi yang berbeda terhadap biomassa dari $S$. platensis dengan sistem semi outdoor memiliki pengaruh yang berbeda-beda, hal tersebut terlihat dari jumlah biomassa yang dihasilkan pada setiap perlakuan yang menunjukkan nilai yang berbeda. Perlakuan A yang diberi tambahan nitrat dengan konsentrasi 7 ppm jumlah biomassa pada hari ke-0 0,183 g dan bertambah pada hari ke-14 menjadi 0,557 g. Pada perlakuan B yang diberi tambahan nitrat dengan konsentrasi 9 ppm jumlah biomassa pada hari ke-0 0,172 g dan bertambah pada hari ke-14 menjadi 0,669 g. Pada perlakuan $\mathrm{C}$ yang diberi tambahan nitrat dengan konsentrasi 11 ppm jumlah biomassa $S$. platensis pada hari ke-0 0,163 g dan pada hari ke-14 jumlah biomassanya bertambah menjadi $0,485 \mathrm{~g}$.

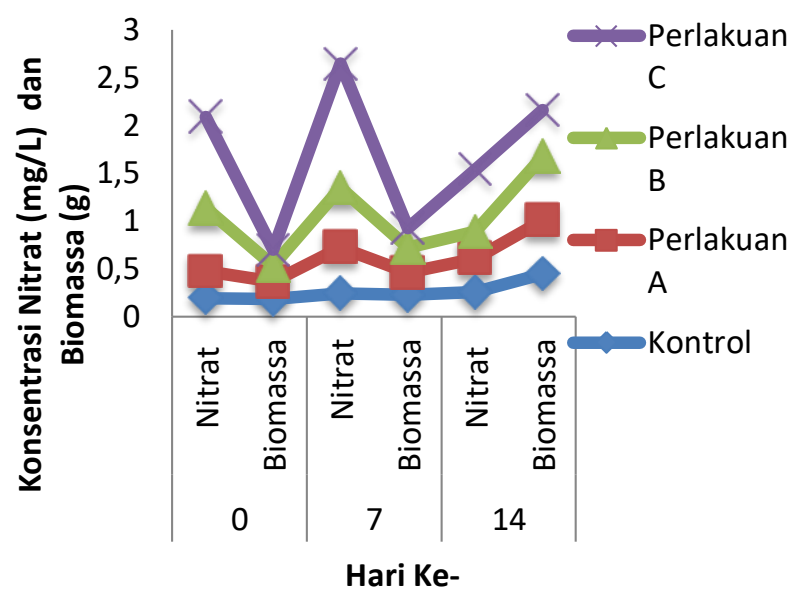

Gambar 2. Perubahan Konsentrasi Nitrat yang Berbeda Terhadap Biomassa $S$. platensis dengan Sistem Semi Outdoor

Jumlah biomassa yang dihasilkan tersebut juga terlihat bahwa konsentrasi nitrat yang baik untuk peningkatan jumlah biomassa $S$. platensis terjadi pada perlakuan $B$ yaitu dengan penambahan konsentrasi nitrat $9 \mathrm{ppm}$, hal ini terlihat dari jumlah biomassa yang tertinggi terjadi perlakuan B yaitu 0,669 $\mathrm{g}$, hasil penelitian ini berbeda dengan penelitian sebelumnya dimana pada penelitian sebelumnya jumlah biomassa yang paling tinggi berada pada konsentrasi nitrat $7,5 \mathrm{ppm}$ (Chrismadha et al, 2006).

ANOVA yang telah dilakukan diketahui bahwa nilai signifikan yang dihasilkan yaitu $\mathrm{p}<0,05$ yang berarti memiliki perbedaan yang nyata. Pada uji lanjut LSD yang 
dilakukan ditemukan perlakuan yang memiliki perbedaan yang nyata dengan nilai signifikan dimana $\mathrm{p}<0,05$ yaitu pada perlakuan Kontrol dengan perlakuan B yang menunjukkan nilai signifikan 0,001, kemudian pada perlakuan A dengan perlakuan $\mathrm{B}$ dengan nilai signifikan 0,016 dan pada perlakuan B dengan perlakuan $\mathrm{C}$ menunjukan nilai signifikan 0,001 .

Jumlah biomassa $S$. platensis semakin hari semakin bertambah seiring dengan adanya penambahan konsentrasi nitrat dengan konsentrasi yang berbeda, hal ini sesuai dengan Viena (2014) yang menyatakan peningkatan biomassa mikroalga bertambah seiring dengan penambahan konsentrasi nitrat. Penambahan nitrat yang berbeda pada kultur mikroalga yang telah dikondisikan akan menunjukkan peningkatan jumlah biomassa yang signifikan.

\section{KESIMPULAN DAN SARAN}

Penambahan kadar nitrat dengan konsentrasi berbeda akan membantu meningkatkan jumlah biomassa $S$. platensis. Kadar nitrat selama proses kultur 14 hari mengalami kenaikan pada hari ke 7 dan pada hari ke 14 kadar nitrat kembali menurun, sedangkan pada biomassa $S$ platensis mengalami peningkatan. Konsentrasi nitrat yang baik untuk pertumbuhan biomassa $S$. platensis berada pada perlakuan dengan penambahan konsentrasi nitrat 9 ppm (B) dengan biomassa tertinggi yaitu 0,669 gr.

Uji lanjut LSD menunjukkan perbedaan yang nyata $(\mathrm{p}<0,05)$ antara perlakuan Kontrol dan perlakuan B, kemudian perlakuan A dengan perlakuan B dan antara perlakuan B dengan perlakuan $\mathrm{C}$.

Penelitian lanjutan dapat dilakukan terhadap faktor-faktor yang menjadi pembatas bagi pertumbuhan $S$. platensis yang dapat mempengaruhi biomassanya.

\section{DAFTAR PUSTAKA}

1. Amini, S dan R. Susilowati. (2010). Produksi Biodiesel dari Mikroalga Botryococcus braunii. Squalen. Volume 5(1)

2. Borowitza, M.A and L.J. (1988). Algal Growth Media And Sources Of Algal Cultures. In Borowitzka, M.A and L.J Borowitza (Eds) Microalga Biotechnology (P. 456-465).. Cambridge University Press: Cambridge.

3. BPPT. (2013). Development of Planning and Policy Support for Improvig the Potential Production of Biogas as Renewable Energy in Indonesia's Tofu Industries, Renewable Energy-Efficiency Energy Partnership (REEEP) Environmental Technology Centre, The agency for the Assessment and Aplication of Technology.

4. Chrismadha, T., L.M. Panggabean, dan Y. Mardiati. (2006). Pengaruh Konsentrasi Nitrogen dan Fosfor terhadap Pertumbuhan, Kandungan Protein, Karbohidrat, dan Fikosianin pada Kultur Spirulina fusiformis. Berita Biologi volume 8(3) Pages 163-169.

5. Rahayu W. (2007). Isolasi dan Optimasi Parameter Lingkungan Kultur Spirulina sp. dalam kondisi laboratorium. Thesis. Bandung : Institut Teknologi Bandung.

6. Susanna, D., Zakianis, E. Hermawati, dan H.K. Adi, (2007). Pemanfaatan Spirulina platensis sebagai Suplemen Protein Sel Tunggal (PST) Mencit Mus musculus. Makara Kesehatan volume 11(1) Pages 44-49. 
7. Ulya, S. (2018). Kandungan Protein Spirulina platensis Pada Media Kultur Dengan Konsentrasi Nitrat $\left(\mathrm{KNO}_{3}\right)$ Yang Berbeda. Semarang:Buletin Oseanografi Marina. Volume 7(2) Pages 98-102.

8. Viena, V. (2014). Kultivasi Mikroalga Hijau pada Sumber Nitrogen Berbeda Untuk Ekstraksi Lipida. Jurnal Puriffikasi, Volume 14 (2) pages 99 - 105. 